\title{
The Book of Examining the Summary (Tamhees Al-Talkhees) (Science of Meanings) by Hassan Kafi Al-Aqsaari Al-Bosnian (1025 A.H.)
}

\author{
Nada Abdullah Hassan
}

Supervised by

Prof. Dr.Firas Abdul Rahman Al-Najjar, 1441 AH, Surah Yusuf: from verse 76

\begin{abstract}
Keywords:

Article Received: 10 August 2020, Revised: 25 October 2020, Accepted: 18 November 2020
\end{abstract}

\section{Introduction}

Praise be to Allah, the thanked one, and may prayers and peace be upon the last of the prophets and messengers, Muhammad bin Abdullah Al-Sadiq Al-Amin, and upon all his family and companions. Then, an investigation is the tendency of many students to contribute to reviving the Arab literary heritage and spreading the treasures of our Arab and Islamic culture, as well as a humble service to enrich the literary, as a tribute to our distinguished scholars and spreading their knowledge. My desire to investigate after consulting with people and experience was a strong motivation behind my pursuit of this noble goal. From this standpoint, I tended to achieve this literary rhetorical manuscript.

\section{Research included two parts:}

The first: it included a translation of the author of the book (Hassan Kafi Al-Aqsari in Bosnia).

The second: it included achieving the first original of the manuscript which is in the science of meanings.

When I studied the manuscript, I followed a series of steps to bring the manuscript to light, starting with choosing the mother copy and then comparing it with the rest of the copies, explaining the difference between them, leading to the analysis of the texts contained in the manuscript, whether they were Qur'anic verses, prophetic hadiths, poetic verses or vague words by referring to Books of exegesis, collections, and dictionaries, with translations of the characters mentioned in the manuscript. Then, I arranged the sources and references, and an index of the contents. Then, I relied on my study on several sources, which varied between books of interpretation, hadith, language, grammar, rhetoric, literature, and books of translations ... and finally ... I ask Allah - glory be to Him - that I have succeeded in producing this manuscript in a way that pleases Allah, glory be to Him, and then pleases my teachers, Allah I ask to guide us to the straight path.

And Praise be to Allah, the Lord of the Worlds.

The researcher

Preface: the author's personal life

His name and Family 
We rarely find a translation of the author in the books of translations, and what was mentioned in the sources is nothing more worthy of mention than what he mentioned in the book Nizam al-Ulama to the Khatam al-Anbiya, and in it, he mentioned the chain of his sheiks to the Prophet, peace be upon him, and he also referred to the famous students of his time, and each one translated a translation Good deed.

His name is Hasan Bin Torkhan Bin Dawood Bin Ya'qub Al-Aqsaari, the most famous of Kafi Al-Busnawi, Al-Qadi, the grammatical jurist, the fundamentalist, the speaker, the poet, the reformist, the Mujahid in the cause of Allah, and he was the chief of scholars and virtues in his era (1).

The book "The System of the Scholars to the Last of the Prophets" to the author - may Allah have mercy on him - is one of the most important sources for his translation, and many researchers have relied on it in researching his biography, and what the author of the book kept silent about remains unknown to us. There are no other sources about it until we rely on it to clarify the different angles of His biography and scholarly life.

The author says about his family: "My father, may Allah bless him with his forgiveness and some trustworthy peers from his peers, narrated that his grandfather, MarkoumYaqoub, lived two hundred and twenty-seven years." Historian Salih Effendi, the author of the book DiyarBosna, mentioned that he lived one hundred and twenty years. (2).

Then, the author said: "His birth (i.e., Ya'qub) was on the Roman side of Alexandria, then he traveled to the village of Dhib and Wakuh, in the district of Akhsar, while he was a Christian. Then, Allah Almighty Al-Ghaffar guided him, and he converted to Islam upon the coming of $\mathrm{Abu}$
Al-Fateh, Sultan Muhammad Khan, to open the homes of Aqsar and lived in the early Sultanate of Sultan Suleiman, may Allah have mercy and forgiveness on him (3). Akhisar is a Turkish word meaning the white city (Biograd), and it is a literal translation of the city's name for its original inhabitants.Then,Prusac became known to them, and it exists today with this name (4).

According to what the author says (5) that Jacob, the grandfather of his father, converted to Islam after the year $867 \mathrm{AH} /$ $1463 \mathrm{CE}$, that is, after the great conquest by Sultan Muhammad al-Fatih, and he lived in Islam until the early Sultanate of Sultan Suleiman Khan (926-973 AH / 1520-1566 $\mathrm{CE})$.Then, the author says: My late grandfather David lived seventy years and witnessed invasions and then was martyred when the fortress was besieged: "Wranh" from the fortresses of Croacia (6) and "Warana" is the city of "Vranica" today, which is located south of Zenica in Zenica. Bosnia and close to the town of the author David's grandfather.

(1) Kafi, Nizam al-Ulama to Khatam alAnbiya, p. 30.

(2) Al-Khanji, Al-Jawhar Al-Asna in the translations of Bosnian scholars and poets, p. 50.

(3) Kafi, Nizam al-Ulama 'to Khatam alAnbiya', p. 30.

(4) ZuhdiAdilovic Al-Bosnian, Introduction to the book Nour Al-Yaqin fi Usul al-Din by Hassan Kafi, p. Sesheim, "Akhsar" in: The Islamic Department of Knowledge, translated by: Muhammad Thabet Al-Fandi and others (Cairo: 1352 AH / 1933 AD), Part 2, p. Simskeltza was conquered by Mustafa Pasha in the year 907 AH / 15011502AD. 
(5) Kafi, Nizam al-Ulama to Khatam alAnbiya, p. 30.

(6) Defeats or losses Ukraine is located to the west of the Republic of Bosnia and Herzegovina.

The author said on the authority of his father: "My father - may Allah have mercy on him - lived ninety-six years of consent and righteousness.Then, he died shortly in the day of the year ninety-four, nine hundred may Allah forgive them" (1).

\section{His birth and his upbringing}

Then, the author said about his birth and upbringing: "And I heard from my late mother that this weak slave was born by the grace of Allah on Friday after the afternoon of Ramadan in the year fifty and nine hundred at the time of Sultan Suleiman Khan, son of Sultan Salim Khan, son of Sultan Bayazid Khan, son of Sultan Abi Al Fath Muhammad Khan on them May Allah have mercy on him, the Most Merciful"(2). The author was brought up in the golden age of the Ottoman eras, and the Ottomans surpassed various European countries militarily, administratively, and politically. Sultan Suleiman the Magnificent led the war with thirteen campaigns, ten of which were in Europe, and three in Asia.Thus, he expanded the borders of the Sultanate, codified laws and legislations, and his days were an era Bani Othman Al-Dhahabi (3).

Then, the author said about his translation: "I began to acquire knowledge when I was twelve years old." (4). This means that he began acquiring knowledge in $963 \mathrm{AH} /$ $1555 \mathrm{CE}$, and it is possible that like all Muslim children he learned to read the Qur'an and memorize hadith and some of the basics of the Islamic religion in one of the affiliated local libraries for mosques, and our sources do not give us any information about his life after birth until the year 963 $\mathrm{AH}$, he was twelve years old, and he joined one of the schools in his country at that time, and it is possible that he was educated in one of the three schools in Bosnia at that time, which is the FayrouzBey school that was established around the year 1512 AD. The Khosroubak School, which was founded in 1537 AD, and the Kamal Bey School, which was founded in 1540 AD (5).

\section{His death}

Historians (6) are unanimously agreed that the date of his death was the year $1025 \mathrm{AH} /$ $1616 \mathrm{CE}$, and they mentioned that he was buried in the mosque that he built, but ZuhdiAdilovich mentioned the date of his death in the year $1024 \mathrm{AH}$, and he said:

"The owners of the translations who translated for him mentioned that his death was the fifteenth night of Sha'ban year 1025 $\mathrm{AH}$, as he mentioned this in the manuscripts of some of his books, but I found in some other manuscripts he mentioned the year $1024 \mathrm{AH}$. There is also a manuscript of his book, Nizam al-Ulama, which was reproduced from the author's copy in the year $1026 \mathrm{AH}$. For two years after the author's death, this manuscript was found in the Fawziaschool in Travnik, which is 45 kilometers from the author's town, so it is likely that it was the work of one of his students, especially since he mentioned at the end the names of some of the author's students who had studied with him in his hometown, and ismentioned in that manuscript that he passed away on the sixteenth day of Ramadan $1024 \mathrm{AH}$, then wrote the following verses:

(1) BaniMarjeh, The Sick Man's Awakening, p. 41-42.

(2) The previous source, p. 30.

(3) BaniMarjeh, The Sick Man's Awakening, p. 41-42. 
(4) Kafi, Nizam al-Ulama to Khatam alAnbiya, p. 30.

(5) Adilovitch, Introduction to Nur al-Yaqin fi Usul al-Din, p.30.

(6) Bruce Lee Muhammad Taher, OthmanliMovelri (Istanbul: Amra Press, 1333 AH), vol. 1, p. 277, Haji Khalifa, Kashf al-Zunun (Beirut: Dar al-Fikr, 1402 AH / 1982 CE), Part 2, pp. 1002, 1082, 1143, Shalabi, that of history, Vol. 1, p. 380, as a case, The Authors 'Dictionary, Part 1, p. 556, Al-Zarkali, Al-Alam, vol. 2, p. 194, Al-Baghdadi, A knowledgeable gift, the names of the authors and the effects of the compilers from Kashf al-Zunun (Beirut: Dar Al-Fikr, 1402 AH / 1982 AD), Part 1, pp. 291-292, SassheimIqsar, in: The Islamic Encyclopedia, Part 2, p. 460.

The date of the death of Kafi Sheikh Hassan Effendi, the judge and Mufti of Ikhsar AlAqsari

Before the phone, this date he won a face, escape, and happiness

If we collect the value of the numerical letters in the other ways of the second house, we find that it is $1024 \mathrm{AH}$, which is the year of his death, and he was buried with his wife in a room under the court building, and this building exists to this day in the shape that he built - may Allah have mercy on him twenty meters from the right side (1).

But I do not think this statement is correct, and what is more likely to me is the wellknown saying: Because the manuscript that the aforementioned researcher spoke about is currently in the Ghazi KhusrawBey library under the number 946 , and was reproduced by Khalil al-Nawabadi (d. 1026 $\mathrm{AH}$ ), a student of Hasan Kafi, from the handwriting of the author and the scribe. To the author - may Allah have mercy on him that the date of the author's death was the year $1025 \mathrm{AH}$, not the year $1024 \mathrm{AH}$, the copyist said: "By Allah, I know the right thing and the authority of the reference and money and praise be to Allah, the Most Glorious, and prayers be upon Muhammad, his companions, and the family, to his poor editor. To Allah Al-Bari Kafi Al-Aqsaari. The honorable message of our professor of science, Hasan Effendi, late in the year 1025 $\mathrm{AH}(2)$.

(1) Adilovitch, Introduction to Nour AlYaqin in the Fundamentals of Religion, p. 38.

(2) Kafi, The Book of Propaganda for the Origin of Sharia from his book Sharh alKubiyat, the total manuscript number 946 in the GaziKhusrawBey Library in Sarajevo, in the handwriting of Khalil al-Nawabadi, the student of Hasan Kafi al-Iqsari, and folio 53, and also in the copy of Saif al-Qudah in the ta'ziz of the same author, the aforementioned total, paper 57

\section{In the name of Allah the Merciful (1)}

Praise be to Allah, who created man's knowledge of the statement, and blessings and peace be upon his beloved. The statement is true, so the tongue is clear, Muhammad who was confused (2) with his eloquence, Qahtan was clear, and with his eloquence was unable to the scholar Adnan, and on his family and companions of virtue and gratitude.

And after when the science of rhetoric was one of the most elevated sciences in its understanding and acquisition, and the dearest art in meaning and articulation, it reveals the veil of facts of brevity and minutes of mysteries in all sciences and knowledge, and by it, it stops on knowing what in the Qur'an systems of miracles and secrets of jokes and gentle, and the summary 
by al-Qazwini (3) has the mercy of his rich Lord as a key to the doors of the treasuries of his bases of pearls, a lamp (4) in the darkness of the minutes of his deceptive returns, worthy of being blown with the gold of the sun on the page of the silver of the moon, but it is not without (5) busy objections to the seekers, and obstructive disputes (6) for those who wish.

By seeking some of the bags (7) - those who have come from me in good familiarity with the eye and the head - I clarified what is meant by the fundamentals and the yield of benefits (8) by citing the easiest examples and similar evidence, and I made it a useful summary for beginners, clear without boring, and travel (9) good for the beneficiaries, a mediator without prejudice, apologizing for the lack of insufficiency and seeking help in the tasks of matters, I arranged it on an introduction, two originals and a continuation.After revision and scrutiny, I called it "summary scrutiny."

The purpose of what I ask from Allah and hope for it is to make it sincere in its face and approval and benefit from it as well as its origin by Allah manna and his virtue.

\section{Introduction to eloquence and rhetoric}

The speech and the speaker are described by the two and the singular is eloquence only, as it is in it: its freedom from letter dissonance, strangeness, and contravention of analogy.

So the dissonance is as in (10) the chancelleries (11), and the strangeness is about [from the sins] (12).

(1) The basmalah is proven by $(\mathrm{S})$.

(2) (Affham): In (PBUH): (Inset).

(3) Summarizing the Muftah, in the meanings and the statement by Sheikh Imam Jalal al-Din: Muhammad ibnAbd al-Rahman
al-Qazwini, al-Shafi'i, who is known as the Khatib of Damascus, (d. $739 \mathrm{AH}$ ), and it is a famous text that he abbreviated from the third section of the book Miftah al-Uloom by al-Sakaky, and added to it the benefits of his own. See: Detecting suspicions 1/473, and gift of knowledgeable 2/150.

(4) In (PBUH): (and a lamp).

(5) In (p.): (On).

(6) On the margin: (i.e., shutters).

(7) The Kiss: Contrary to Foolishness, i.e.: the community of opinion and reason A man is a sack, meaning: cute. See: Sahih (Case) 3/972, and Arabic Language Standards (CASE) 5/149.

(8) In (s): (grammar).

(9) The Book: The Book. See: Al-Ain (Safar) 7/247, and Tahdheeb Al-Lughah (Safar) 12/278.

(10) (As in ): not in (s).

(11) Seashir: to twist the rope up, and Alshzar: height. Rather, the dissonance came from the word (mentorship) because it is heavy on the tongue and it is difficult to pronounce it.

(12) The incapacity of a house for the famous poet ivy, and the completeness of the house is:

And a glazed eyeball and eyebrow

And a burner, and a lampstand

Flexor: the nose. And the lamp: it came to him that he wanted the lamp: the specified, from their saying to the swords: the surajiyat Attributed to Ken, known as Sareej. This intent on what you see as a strange wild. See: Diwan al-Ajaj 2/34, the secret of eloquence by IbnSinan al-Khafaji, p. 71, and Asrar al-Balagha, p. 31, and clarification, $1 / 24$.

And a walled mooring 
And the violation (1) as in Praise be to Allah the best (2).

And in speech: his concealment with the eloquence of his words from their dissonance, weakness of composition (3), and complexity (4).

The dissonance as in [from the sins] (5):

And not near a grave, a war, a grave

Weakness is about: his boy struck Zaid (6), and the complexity is about his saying in the maternal uncle of Hisham (7) [from the long] (8):

What is like him in people but an owned

His mother's father is alive, his father is close to him

That is, it is a neighborhood that is approached by none other than the possession of its mother's father, his father. And moving as in [from al-Taweel] (9):

And Al-Ajaj: He is Abdullah bin Ra'ba bin Labeed, nicknamed Aba Al-Sha'ath, and he is known as Al-Ajaj, he realized the Umayyad state, (d. $90 \mathrm{AH})$. See: poetry and poets by IbnQutaybah 2/575, and the infection in distinguishing the Companions $5 / 68$.

(1) Contravention: if the word contradicts the vocabulary of the used expressions; I mean: contrary to what is proven on the authority of the one who established it See: Al-Desouki's footnote on the summary of meanings, p. 165.

(2) A reference to the house of Abi al-Najm al-Ajali, in which he says of al-Razz:

Praise be to God, the Most High

You are the Angel of men, so receive

And the poet contradicts the analogy in (alAjlal) by eliminating sluggishness that disturbs eloquence, and eloquence: (the delay), which is the analogy. See: clarification $1 / 26$, and the treasury of literature by Al-Baghdadi 2/392.

(3) Weakness of composition: violating grammar in speech. See: Desouki's footnote $1 / 111$.

(4) Complication: the speech should not be apparent to indicate a defect. See: The longest Explanation of Miftah al-Uloom by Issam al-Din al-Hanafi 1/12.

(5) (War of the grave): Not in (S). The helplessness of a house that the one who said it does not know, and al-Qazwini said: A phone from the jinn shouted war against IbnUmayya, so he died, and that genie inherited him in this house. And its completion:

And a grave of war in a place of wilderness

Harb: a man's name. Al-Wafr: devoid of water and pasture. See: Al-Bayan and AlTabiyyin by Al-Jahiz 1/16, Al-Badi fi Criticism of Poetry by Muayad Al-Dawla, p. 161 , and clarification $1 / 30$

(6) The face of weakness in it: the pronoun in (his boyfriend) is late in pronunciation and rank, and it is the object. Therefore, if you want to correct the issue, you must delay the subject and say: Zaid struck his boy. See: AmaliIbn Al-Shajri 1/152, and AlCharacteristics by Ibn Jinni 1/295.

(7) Hisham bin Abd al-Malik bin Marwan: one of the kings of the Umayyad state in the Levant. He was born in Damascus, and was sold there after the death of his brother Yazid (105 AH). He built Rusafa (on four leagues from Raqqa to the west), and he used to live in it in the summer, and he died there in the year $125 \mathrm{AH}$. He was a good politician, vigilant in his affairs, and would do business by himself. See: The History of Damascus 74/22, and the date of Thursday 2/318. 
(8) The house is attributed to FarazdaqHammam bin Ghaleb bin Sa`sa (d.110 AH), and I did not find it in his office, praised by Ibrahim bin Hisham bin Ismail al-Makhzoumi, who is the maternal uncle of Hisham bin Abdul Malik. And by the king he means: Hisham, the father of the mother of that king, the father of this praised one, and if these words were on his face, it would have been ugly, and if the words were put in place, he would say: And what is like him in the people is close to him except for the king of the father of Umm this king, the father of this praised. That he was his uncle with this distant expression, and he offended him with what he made of the introduction and delay. See: al-Kamil al-Mubarrad 1/28, and al-Usul fi al-Naama by IbnSarraj 3/467.

(9) The deficit of the house of Abbas bin AlAhnaf, the Abbasid poet (d.192 AH), and his chest:

And my eyes poured out tears to freeze

The transition from inertia to miserliness with tears is not the intended pleasure.

And in the speaker (1): a talent that is capable of expressing (2) the intended meaning in an eloquent expression and eloquence in it: a queen by which he can compose an eloquent speech, so every eloquent is eloquent without the opposite.

In (3) the speech corresponds with his eloquence to the necessity of the situation, which is the appropriate consideration for the position, which is different (4) according to the difference in the denominators of speech. The elevation of its status in the good and the acceptance of its conformity with the appropriate consideration and its degradation by lack thereof.

Rhetoric refers to phrasing, considering his statement the meaning of syntax, and in speech, it has two sides: superior; It is the limit of miracles, and below; What if it is changed to what is below it is considered from the sayings of the common people, and there are many ranks between them, and its reference is three: distinguishing the eloquent from others, guarding against error in performing the desired meaning, and guarding against moral complexity.

The first of it: What (5) is known as the body of language, morphology, grammar, or sense perception.

The second: knowledge of meanings; It is a science by which he knows how to apply speech to the necessity of the situation, and the third: knowledge of the statement which is a science by which it is known to include the same meaning in different ways in terms of clarity of significance (6) and its continuation: what is inherited by speech well and is known as knowledge of the good it is a science in which aspects of improving speech are known after taking care of conformity to the necessity of the case and clarity of connotation.

The first original science of meanings (7), which is eight chapters

The first chapter in the conditions of the informative and news attribution

The chain of transmission is a mental fact. It is: assigning the verb or its meaning to what he has according to the speaker on the surface, such as when the believer says: Allah spreads the legumes, the saying of the ignorant: The spring spawned the legumes, and the Mu'tazili saying to the one who does not know his condition: Allah created all actions (8), and your saying Zaid came, and you know that it is He did not come.

And from it is a mental metaphor, which is its attribution to clothes for him with an interpretation (9) so about his saying [from al-Razz] (10):

After the house I will ask you to come close 
See: Al-Kamil 1/163, and Al-Durr Al-Farid by IbnAydamer 5/409.

(1) That is, eloquence in the speaker is ...

(2) In (q) addition: (compose).

(3) In (PBUH): (and rhetoric in).

(4) In (s) increase: (in).

(5) (Ma): not in (PBUH).

(6) In (s): (semantics), and in (pbuh) addition: (it).

(7) Not mentioned in (s).

(8) This is an example that matches reality without belief, and there is hardly an example for him except this. See: Al-Tawlal $1 / 260$, and Science Al-Balaghah by Maraghi, p.

(9) In (Q, PBUH): (Bawl).

(10) The three verses of Abu al-Najm alAjli, and their completeness:

Than if she saw my head like a bald head

He distinguished himself from his disguise from his disguise, to attract nights slow or faster

A gray horn and a century, so swallow away our perishing. God says to the sun, come up

Till if I see you go back

He distinguished himself (1) from him from disguised himself from disguises

Attract nights slower or faster

He bears on the metaphor with evidence that he said Aqiba [from al-Rizzi]:

I consume it, is it that Allah told the sun: Go forth

No saying [from the convergent] (2):

To be the youngest and most to the great

Repeat the meal and the evening pass
Unless it appears that what he said is not apparent.

Also, in the construct (3), and also touches the subject (4), and the object (5) as in the Sali (6) and the stem of the verb as his grandfather's grandfather (7), and time; Like the day is fasting, and the place; as: a running river (8), and the reason; As in : The Prince built the city.

And its edges (9) are either two facts about: the spring brought forth grass, or metaphors toward The earth revived the youth of the time, or they differed toward: the ground raised the youth of the time, and toward: The earth revived the spring, and his condition is a verbal presumption as passed by his saying: (We finished it).

Or the moral, such as the impossibility of the predicate being assigned to the mentioned ascribed in reason, such as your saying: Your love brought me to you, or a habit as in the prince defeated the army.

Knowing his truth is either apparent. As in the words of the Almighty: (10) that is, they did not gain in their trade (11), or it is hidden; As it says [from the fragmentary of al-Wafir] (12):

His face increases you well

If you increase it looking

All of this is a metaphor, making the verb to the nights and their passage, except that it is invisible, not the beginning of the page, then he explained and revealed the way of interpretation, and reported that he built his first words on imagination and said: We have made the verb to God Almighty, and it is the originator and the initiator. See: Asrar al-Balaghah, p. 390, and Miftah al-Uloom, p. 394.

(1) Not in (p). 
(2) Al-Bayt for the two prayers Al-Abdi QothamIbnKhubayyah (d. $80 \mathrm{AH})$. It is one of the convergent and metaphor for actually proving graying for days and dark nights. Seen: Full 3/135

(3) SuratGhafir, some verse: 36.

(4) Surat Al-Qarah, some verse: 7. What is meant is: satisfactory. See: Samat Al-Alli Al-Bakri 1/396, and illustration 1/87.

(5) In (pbuh): (or object). We have proven it first

(6) In (p. And in (s): (intercalated torrent). This example is constructed for the object and attributed to the real subject. Because it is the torrent that breathes; That is, it fills, and its origin is: the torrent filled the valley, that is, it filled it, then built the most virulent for the accusative. See: Desouki's footnote $1 / 413$.

(7) The grandfather was assigned to the grandfather, meaning: the diligence, which is not its subject, but its serious subject and its origin: very serious, meaning: diligence, so he deleted the original subject, which is serious, and assigned the action to the grandfather. See: Sciences of Rhetoric, p. 292.

(8) Fasting is attributed to the day and running to the river, and all of these are a time and place for action that have no reality. See: Sciences of Rhetoric, p. 292.

(9) That is, the mental metaphor, considering the two ends of the predicate and assigned to it are only four sections. See: illustration p.92.

(10) Surat Al-Baqarah, some verse: 16. See: Jami Al-Bayan Al-Tabari 1/317, Bahr AlUlum by Samarkandi 1/30.

(11) See: Jami al-Bayan al-Tabari 1/317, Bahr al-Uloom by Samarqandi 1/30.

(12) Al-Bayt is from Mjzoo 'Al-Wafir, and it is attributed to Abu Nawas Al-Hassan Bin
Hani (d.199 AH), and it was said: to AlAbbas Bin Al-Ahnaf, and it was said: by Ibn Al-Mu adhil. See: The Good Companion of Abu Al-Faraj, p. 72, Diwan Al-Maani, 1/231, and Miftah Al-Uloom, p. 397.

That is, may Allah increase you well in His face (1).

As for the news: it may be intended to inform the addressee either as a judgment, or because he is aware of it, and the first is called: the benefit of the news, and the second: it is required, and the knowledgeable person may assign them the status of the ignorant, for not running according to the necessity of knowledge, such as your saying: Prayer is obligatory for the scholar who left it, so the speaker is limited to what is needed.

The mindlessness of the judgment and the hesitation in it is not assured of it, and it is called elementary, and the hesitant student has the right to strengthen him with an affirmative, and he is called a request, and for the evil one must emphasize it according to the denial, and he is called denial, and all of it is the output of speech according to the apparent necessity.

And it may come out unlike him, so the nonliquid is made like the liquid if something is presented to him that makes him like the honorable (2), as in (3).

And the evil is like the evil if something of the signs of denial appears on him, as in [from the fast] (4):

A brother came by cutting his spear

Indeed your uncle's sons have spears in them

For those who have a deterrent, if you contemplate it, it will be deterred, such as your saying: Islam is a right for a denier with evidence of its truth (5) and so are considerations of negation. 
The second chapter in the conditions of Subject-predicate structure

As for mentioning it, it is because it is the original and it is not necessary to deviate from it, or to prevent weak reliance on presumption, or to alert the listener to foolishness, or to increase the clarification and report. As the Almighty said righteousness (6), or to show his veneration.As in the Commander of the Faithful is present, or his insult. As in, a mean thief is present, or being blessed by his mention; About: The Messenger of Allah said this saying, or its extrapolation; Approach: the beloved is the present, or simple speech where listening is required; Syntax (7) or something similar.

As for itsinversion, because its mention is more important, either because it is the original as passed, or to enable the news in the mind of the listener, such as its saying [from the light] (8).

In which the wilderness ablated

An animal developed from an inanimate objectOr to hasten pleasure in optimism as in happiness is in your home, or mischief in the direction of the thug is in your home, or to make the illusion that it does not pass away from the mind, or that he is enjoying, or to use it as actual news if the character of negation is about: what I said this; that is, I did not say it even though it was said, otherwise it may happen in response to the one who claims that someone else is alone with him or his participation in it as in I sought your need, and he emphasizes the first in terms of not someone else, and on the second by alone.

And (1) may occur to strengthen the ruling as in He gives the thanks, as well as in the act of exile as in You did not seek in my need (2), and about You do not lie, and in building on the indefinite structure which indicates the allocation of the sex or one as in a man who came that is no woman, or no two men.

As for defining it, the statement of the addressee has the most benefit, and it is used in the denomination of speaking, as in I hit, and backbiting (3) toward $\mathrm{He}$ hit, or speech toward: You hit.

And its origin is for a specific one, and it may be for someone else to generalize every addressee as in It is not for me (4).

And scientifically; to bring it into the mind of the listener starting with his name, as in not mine (5), or his desire as in [from the simple] (6):

Nights of you or nights of human beings

Or blessing him as in Allah the Guiding, or glorifying or insulting; such valid titles are about: Muhammad is the beloved of Allah, and Satan is the enemy of Allah or a metaphor for: Abu Lahab did such-and-such, or the like.

And concerning distinguishing it complete distinction, as in [from the simple] (7):

This is Abu Al-Saqr, an individual in his good deeds

Or exposing the listener's idiocy as saying [from the long] (8):

Those are my fathers, bring me something like them

(1) (That is, Allah will increase you well in His face): Not in (S).

(2) In (PBUH): (as the Supervisor).

(3) SuratHud, some verse: 37 . This is a measure of caution, because when He told the death of those who perished in the flood, He followed him by praying for the perished and describing them with injustice, so that he knew that all of them were worthy of torment. Beware of the weak and deluded 
that the destruction may include those who do not deserve the torment, and it appears from that the sincerity of his promise to his prophet Noah, peace be upon him, and we are informed that he has fulfilled his promise, which he told in the verse. See: Tahrir Al-Inking by IbnAbi Al-Isba, p. 246.

(4) The House of Hajl Bin Nidal; One of the sons of Amr bin Abd bin Qutaybah bin Asar is a Jahili poet. Brother: A man's name. Displaying his spear: that is, placing him on the width by making it while riding on his thighs, he does not deny that there is a spear in his cousins, but his coming thus putting the spear on the width without turning around and preparing a sign that he believes that there are no spears in them, but all of them are defenseless and have no arms with them And it was given the status of evil. See: Al-Bayan and Al-Tabiyyin: 3/222, and Al-clarification 1/74.

(5) In (s): (his truth), and in (pbuh): (truth).

(6) Surat Al-Baqarah, verse: 5.

(7) SuratTaha, some verse: 18.

(8) The House of Ahmed bin Abdullah AlTanoukhi; Known as Abu Ala Al Maarri. What is meant by the animal is: the human being, and his saying: created from inanimate objects: he wanted the sperm on the basis that what is meant by inanimate objects is that which is not an animal even if it is separated from it, or that what is meant is created from inanimate objects, considering its origin and it is the mud of Adam, based on that what is meant by inanimate objects is what is not an animal and is not separated from it, or What is meant by the animal is the bodies emerging from the graves, which are created from inanimate objects, which is the soil from which they grow. See: Fadl al-Zand 2/1400, Miftah al-Uloom p. 183, Verifying the benefits of al-Ghiath by al-Karmani 1/333, and Haashiyat al-Desouki 1/628.
Or to show his condition near, or far away, or mediating, as in this and that and that, or denigrating it close to as in "And when those who disbelieve see you, [O Muhammad], they take you not except in ridicule, [saying], "Is this the one who insults your gods?" And they are, at the mention of the Most Merciful, disbelievers" (1) or venerating it in a dimension as in : to me "This is the Book about which there is no doubt, a guidance for those conscious of Allah" (2) or insulting it as in that damned did such-and-such, or so.

And by the letter (J) in Arabic for referring to (3), or truth about: a man is better than a woman, or absorbing a truth about:

Jalal Lakhch (4) meaning: every unseen and testimony (5), or a convention about the collection of the Emir the goldsmith, that is, the jeweler of his country or kingdom.

And the conductivity, because the addressee was not aware of his status except the connection, such as your saying: Who was with us the most recent man, is a scientist, or the hybrid of the statement by name, or increasing the report as in I did not have to (6) or exaggerating as in : (7), Or alerting the addressee (8) in error as in [from the complete] (9):

For those you see are your brothers heal their chest when you die

Or nodding to the way the story is constructed as in (10) or the like.

In addition, it is the shortest road as in [from the long] (11):

My hobby is with the two Yemen laddering up

To maximize the status of thegenitive constructionas in Abdi came, or the genitiveas in Abd al-Khalifah rode, or 
contempt as in Thumper Zaid and the son of Hijam is present.

As for denying it to individuals as in (12), or the specificity as in (13), or venerating or belittling [from the long] (14)

He has a veil in everything he disgraces

He does not have a veil on the authority of the person who is seeking knowledge.

Or multiplying as in : he has camels, and he has sheep or reducing to $(15)$.

(1) Surat Al-Anbiya ', some verse: 36.

(2) Surat Al-Baqarah, some verse: 2.

(3) Surat Al Imran, some verse: 36.

(4) Surat Al-An'am, some verse: 73.

(5) See: TafseerMuqattal 4/327, and Tafseer Al-Alusi 7/191.

(6) Surat Yusuf, some verse: 23.

(7) SuratTaha, some verse: 78.

(8) (Address): Not in (S).

(9) The house of Abda bin al-TayyibYazid bin Amr bin Ali al-Tamimi (d.25 AH). You see them: you think them. Panic: perish and have accidents. See: Al-Mufadliat, p. 147, and Al-Dorr Al-Farid 4/450.

(10) SuratGhafir, some verse: 60 .

(11) A house was issued to Ja far bin Alba Al-Harithi (d.145 A.H.), and his inability:

My body and my body in Makkah is documented

Elevator: That is, going quickly. See: Explanation of Abu Tammam enthusiasm to Al-Farsi 2/87, and visual enthusiasm 125/2.

(12) Surat Al-Qasas, Some Verse: 20.

(13) Surat Al-Baqarah, some verse: 7.

(14) Al-Bayt by Abu Al-Samat, Marwan bin AbiHafsa Al-Shaer (d.182 AH). See: Zahr
al-Adab by al-Qayrawani 2/551, and the end of al-Arb 3/183.

(15) Surat At-Tawbah, Some Verse: 72.

As for its description, the disclosure is about: the long, wide, and deep body of an accident, or the specification as in the merchant added to us, or praise or slander as in Zaid of the world or the ignorant, or mercy as in Zaid the poor; When it was appointed before it was mentioned, or the affirmation as in Yesterday was a great day.

As for its confirmation, for the report, or against the delusion of forgetfulness (1), or metaphor as in : the authority itself used, or the lack of comprehensiveness as in "So the angels prostrated - all of them entirely" (2).

As for its statement of kindness, to clarify it with a name that is specific to it, as in Introduce (your friend Khaled.

As for changing it, then adding the report (3) as in Your brother Zaid came, and the people were most of them, and Zaid was robbed of his garment.

As for sympathy for him, detail it with an abbreviation as in Zaid and Amr came, (or the Musnad also came as in Zaid came, Amr, or then Amr) (4), or the people came up to Khaled, or the listener returned to the right as in Zaid came, not Amr, or the judgment was dismissed To the last approach: Zaid came, rather Amr, or what Zaid came, but Amr, or doubts or doubts about Zaid came or Amr.

As for separating it with the pronoun, assign it to the Musnad "subject" with the following" Indeed, it is Allah who is the [continual] Provider, the firm possessor of strength" (5).

Concerning its deletion, it appears with evidence about [from Al-Khafif] (6):

He told me how you are, I said: ill 
Or experiencing the attention of the listener in her, or the extent of his alertness when hidden, or guarding it against your tongue in veneration, or reversing it, or facilitating denial as in an immoral adulterer, or his designation as in the creator of what he wills.

As for delaying it, it is necessary to provide the (Subject) Musnad.

This is what appears to be the case, and it may contradict it and others as well.

From it: to place the implicit position in the position of the appearance so that in the mind of the listener what follows it as in him or her, the place of the affair or the story.

And from it, it is opposite, in the name of the indication of perfection of care to distinguish it, for his competence with excellent judgment as saying:

How sane are their doctrines blinded by a sane person

And a foolish, ignorant, ignorant met him

He who left the illusions confused

And the free world has become a heretic (7)

Or mocking the listener, as if he is blind, or calling for the perfection of his dullness or insensitivity, or pretending to appear as in his saying [from the long] (9):

(1) In (s) Ziyadah: (Toward Zaid Zaid came to me).

(2) Surat Al-Hijr, Some Verse: 30.

(3) What is in parentheses is not in (x).

(4) What is in parentheses is not in (x).

(5) Surat Al-Dhariyat, Some Verse: 58.

(6) A famous house was issued that was not attributed to anyone, and its inability:

Permanent watchfulness and long sadness
See: Note $2 / 5$, and evidence of miracles $p$. 238.

(7) Al-Nahrir: the subtle, skillful, wise, and experienced. See: Lisan Al-Arab (Nahar) $5 / 197$.

(8) The two houses are from Al-Basit, and they are by Ibn Al-Rawandi Ahmad bin Yahya (d. 291 A.H.). Blinded: incapacitated, and its doctrines: his means of subsistence, and heretic: the one who underlies disbelief and reveals Islam. See: Miftah Al-Uloom, p. 197, Verifying the Benefits of Ghiyyat 1/388, and Science Al-Balaghah, p.143. The significance of the home is the coming of the name of the sign (this) in the shrine of the conscience (it) to direct attention to thinking about the wisdom of God, appreciating the livelihoods of the servants, and realizing that sustenance may require the wisdom of God. By coming abundant for the ignorant, and coming in abundance for the rational world.

(9) The house belonged to Abdullah bin Ubayd Allah IbnDaminah (d.130 AH), and it was attributed to AliyyahBint Al Mahdi and others. Taal: claim illness and illness. Adhaj: I am saddened by my courage by breaking, to be encouraged by conquest, and by that; That is, by killing me, and he did not say: (with it) to claim that his murder had shown the appearance of the sensual by the sight thatYou have come to be brave and there is no cause by you

You want to kill me, you won by that.

Without referring to the increase in mastery as in, It is not for me (1) or reverence as in : the Commander of the Faithful orders you so, a place: I command you, or sympathy as in [the abundant] (2):

My Lord, your disobedient servant has come to you

A place: I came to you, in which a turn is made from speaking (3) to backbiting, and it 
is permissible to turn back to (4) with and from them to speech as in : (5) and me (6) And from the discourse to each of them about [from the long] (7):

A sweetheart has broken with you

The afternoon of youth is good

He assigned me to Layla, and he sent it to her

Returns between us and engagement

And his saying (8).

And from it: The addressee receives something other than what he is expected to do, by carrying his words contrary to what he wants, warning that he is the first with intent. As the reception of Al-Qabathi (9) and the festival of pilgrims, which is: "I will carry you on the adham" by saying: "The parable of the prince is carried on the adham and the bald eagles" (10) (11) and the like.

(1) Surat Al-Ikhlas, verse: 1-2.

(2) A house was issued to Ibrahim bin AlAdham (d.116 AH), and his inability:

Acknowledging sins, and $\mathrm{He}$ has called upon you

See: Note 2/85, and Desouki's footnote 716.

(3) In (x): (the speaker).

(4) SuratFater, some verses: 9.

(5) Surah Yassin, verse: 22.

(6) Surat Al-Fatiha, verse: 4-5.

(7) The two houses by Laqama alFahalIbnAbdaibn al-Nu manibnQais (d. 20 qa), Taha: Gold And his saying: In Hassan Taroub; That is, he has joy in seeking good looks and being active in their courtship. And her guardian, i.e. her proximity. Returned: it may be from: ordinary hostility; As if the engagement and the swordsmanship have become hostile to him, or if you are the one who came back again; That is, sticks and obstacles that were turning us back to what they were before. And his saying: He assigns me to yaa, and in it he turns from the speech in (you) to speaking, and the apparent necessity (it assigns you) See: Al-Mufadliyat, p. 391, AlUmda 1/159, and Note 2/88.

(8) SuratYunus, some verse: 22

(9) Al-Ghadhban bin Al-Qabthari, bin Hawdah Al-Asadi, then Al-Shaibani, one of the Knights. Exposing the pilgrims: O God, blacken his face, cut his neck, and water me with his blood, so he told the pilgrims that, so he brought Al-Qabathi and threatened him, so Al-Qabathry said: I wanted that sour. The whole story looks at: Proverbs by Ibn Salam, p. 56, the number of proverbs by al-Askari 2/35, and the continuation of raising suspicion $1 / 155$, and the history of Damascus 48/62, 67.

What is meant by the words of Al-Qabathi: Al-Adham means: the Persians who prevailed in blackness until the whiteness was gone, and the gray hairs were joined to it. That is, the one who conquered his whiteness, as he showed the pilgrim's feast in the exhibition of the promise, and received it without what he expected; That he carried Al-Adham in his words to the Persians, and pointed out that the burden on the Persians was the first time that the Prince meant him. Because he who is like him in victory, money and generosity is worthy to give the Persians and give money, not to be hurt and restrained.

(10) Meteors: a white color that blackness breaks through. See: Tahdheeb al-Lughah (Shahab) 6/55, and Sahih (Shahab) 1/159.

(11) See: Proverbs by Ibn Salam p.

And from it: the expression of the future in the form of going forward, as a warning of its occurrence in the direction of (1) a day is 
blown into the images, and those in the heavens and the earth are dumbfounded (2).

And from it the heart if it includes a gentle consideration, such as saying [from AlRazz] (3):

\section{The third chapter in the conditions of the Subject}

As for mentioning it, it is because it is the original, as in , Zaid is standing, or to be on the safe side due to the weakness of reliance on the context, as in "And if you should ask them, "Who has created the heavens and the earth?" they would surely say, "They were created by the Exalted in Might, the Knowing" (4) or exposing the listener's folly as your saying: Muhammad is our Prophet; Who said: Who is your Prophet? Or it must be a noun or a verb, indicating confirmation or renewal.

As for its individuals, it is because it is noncausal with no evidence to strengthen the judgment, and the causal is a sentence that is reasoned with a return to the subject, on the condition that it is a subject-predicate to him in terms of, his father added a starting point, and his father added (5).

As for being a verb, then it is to restrict one of the times most shortly, with a statement of renewal, such as saying [from Al-Kamil] (6):

Or every time you send preaching tribe

They sent me a messenger who is being treated

With regard to its being a noun, the testimony of the lack of them is as saying [from the simple] (7):

The struck dirham is not familiar with ours

But it passes by it while it is going

And restricting the action to an action to educate (8) interest and leaving it to an objection, and with the condition, so a statement has its meaning with considerations that are known only with the knowledge of its tools in detail (9).

As for his denial of the statement of lack of limitation and the covenant, such as your saying: Zaid is a writer and Amr a poet, or for exaggeration as in "his is the Book about which there is no doubt, a guidance for those conscious of Allah" (10), or to contempt as in , He added something.

As for allocating it by adding something like: Zaid is a young man or the description is about: Zaid is a man who is a scholar, so it is not useful.

As for its definition (11), it is the testimony of an unknown judgment for the hearer on a matter known to him by way of another matter like him or a ruling is required as well (1) as in Zaid your brother, and Amr the starting point, and their opposite considering the definition of a covenant or sex in the (lam), then the second may indicate that sex is limited to something to achieve, Zaid al-Amir, or an exaggeration of his perfection in it as in Amr the brave, and the opposite.

(1) See: Proverbs by Ibn Salam, p. 56, the number of proverbs by Al-Askari 2/35, and the history of Damascus 48/67.

(2) The verse is thus written in all copies, and it is common between Surat An-Naml and Surat al-Zumar, as for the verse of the Naml is: محمخمممىمي [The cliques: 68]. Both verses are a witness.

(3) The house of Ru'aba bin Abdullah bin Al-Ajaj (d.145 AH). The mission: the distant reward and the desolate country, the plural: its tasks, the dusty: the stained dust, and the postponement: the parties. He wants: as if his sky is dusted with the color of his land. See: Al-Mawwana al-Amadi 1/218, Dareat 
al-Poetry p. 268, and commentary on evidence of al-Mughni by al-Suyuti 2/971.

(4) Surat Al-Zukhruf, verse 9.

(5) This is contained in contrast to the original one on the one hand that the origin of the news is to be in terms, either for strengthening, because the news in the sentence is stronger than the news in the singular, or because it is causal, such as your saying: He added his father on the basis of. See: Al-TijazAsrar Al-Balaghah AlMoayadBillah 3/154.

(6) The house by Tarif bin Amr bin Tamim al-Anbari. Their guardian: their sheriff. See: Al-Asmaiyat, p. 127, Al-Bayan and AlTabiyyin 3/69, and Explanation of the Writer's Literature on P284.

(7) Al-Bayt by Nadar bin Ja'iya or Ja'iya bin Nadar. Al-Surra: What the dirhams are collected in. See: The End of Arribah 7/61, Note 2/113.

(8) In (PBUH): (Valtrabiya).

(9) In (x): (preference).

(10) Surat Al-Baqarah, some verse: 2.

(11) Bahaa Al-Din Al-Subki said in Arous Al-Afrah 1/363: "If the hearer knows one of two attributes for the convicted person and you want the other to benefit him, then make the known to the hearer a beginner, and the unknown to him news."

As for the fact that it is a sentence, let it be piety as in , Zaid has risen, or because it is a cause (2) as he passed, and its name, validity, condition, as passed, and its adverb to shorten the actual.

As for introducing it, let him assign it to "No bad effect is there in it, nor from it will they be intoxicated" (3) or optimism as in [from the complete] (4):

The days are happy with the bangs of your face
Or an excitement as in [from the simple] (5):

Three of the world shines with its joy

Duha's sun, Abu Ishaq and the moon

Or a warning, starting on a hadith (6) as in [from al-Tawil] (7):

He has endless anxieties due to his arrogance

As for delaying it, it is because the Musnad(subject) mentioned to it is more important as it was passed.

As for leaving it, let us guard against apparent tampering with the narrowness of the standing as in [from the long] (8):

For I am a stranger with it

And about [From theater] (9):

We are with what we have, and you are through

You are satisfied and the opinion is different

Or so.

Know that what is mentioned is not specific to them (such as remembrance, deletion, and others, so whoever has mastered consideration in them) (10) is not hidden from others.

Chapter four in the morphology of the Verb

(1) That is, on a known matter like another.

(2) In (PBUH): (causative).

(3) Surat Al-Saffat, some verse: 47.

(4) A house was issued that was not attributed to anyone, and its inability:

And adorned your meeting years

See: Note 2/136, and Desouki's footnote 2/148. 
(5) The house of Muhammad bin Wahib (d.225 AH) praises Al-Mu'tasim. Abu Ishaq: the nickname of the Abbasid Caliph AlMu'tasim. See: Zahr al-Adab 3/703, and AlUmda 2/139.

(6) (News): in (q): (his experience).

(7) A Bait was issued, it was said: It is for Hassan bin Thabit (d.54 AH), and it was said: by Bakr bin Al-Nattah (d.192 AH), praising Abu Delf Al-Ajali when he killed two horsemen with one spear. And his helplessness:

And his little carelessness is more than eternal.

See: Al-Kamil 3/95, and Miftah Al-Uloom, p. 219.

(8) The deficit of the house of Dhabi bin Al Harith bin Arta Al-Tamimi (d. $30 \mathrm{AH}$ ), and his chest:

And whosoever hath hath gone against the city, his journeys

Qayar: the name of his horse, and it was said: his camel. See: al-Kamil 1/253, note $2 / 103$, and commentary on evidence of alMughni 2/867.

(9) The house by Amr bin Imru 'Al-Qais AlAnsari. See: the collection of poems of the Arabs 1/13, and AmaliIbn Al-Shajri 2/20.

(10) What is in parentheses is not in (x).

The object is mentioned for the statement of being known, and if it is omitted and left as necessary, it does not affect the words of the Highest (1) with the reference meaning (2) starting as saying [from the long] (3).

And how much you have depended from me of bearing an accident

And from the days of sorrow to greatness

Or wanting to mention it second; to show the perfection of taking care of the

www.psychologyandeducation.net occurrence of the act upon him, as saying [from the light] (4):

We have asked, but we have not found you in trouble.

Dine, glory, and honor, for example

Or a generalization in brief as in "And Allah invites to the Home of Peace and guides whom He wills to a straight path" (5), or just abbreviation as in (6) "And when Moses arrived at Our appointed time and his Lord spoke to him, he said, "My Lord, show me [Yourself] that I may look at You." [ Allah ] said, "You will not see Me, but look at the mountain; if it should remain in place, then you will see Me." But when his Lord appeared to the mountain, $\mathrm{He}$ rendered it level, and Moses fell unconscious. And when he awoke, he said, "Exalted are You! I have repented to You, and I am the first of the believers" (7), or a comma foster as in "And [by] the night when it covers with darkness" (8), or hybrid mentioning it as in : "I did not see him nor did he see me," (9), or something similar.

And presenting it to the effect of it in order to attest the specialization of the appointment, or rejecting the mistake in believing the opposite, or participating as you say: I know more for those who hesitate that you are Zaid, you know a mother or age, or he believes that you have known a life without Zaid.

He confirms (by no other, or the belief in sharing, and confirms) (10) by alone, or to breach the meaning in the delay as in "And a believing man from the family of Pharaoh who concealed his faith said, "Do you kill a man [merely] because he says, 'My Lord is Allah ' while he has brought you clear proofs from your Lord? And if he should be lying, then upon him is [the consequence of] his lie; but if he should be truthful, there will strike you some of what he promises you. Indeed, Allah does not guide one who is a 
transgressor and a liar" (11) and the subject because it is more important than, killing the external so-and-so, or a comma (12) Syntax.

(1) Surat Al-Zumar, some verse: 9.

(2) Surat Al-Nahl, some verse: 9.

(3) Al-Bayt Al-Buhtri Al-Walid Bin Obaid (d. 284 A.H.) Zad: pay, Surat Al-Ayyam: its severity and its reach. Of prejudice: the prejudice of so-and-so against so-and-so if he does not right Melancholy: chop. The interpretation of his words is that if he said: The flesh was grieved, it is permissible for the listener to fantasize before mentioning the following that the slitting was in some meat and did not end up with the bone, so he left the mention of the flesh to absolve the hearer of this illusion. Except for the bone. See: Diwan Al-Buhtari 3/2018, Note 2/156, and Wedding Bride 376/1.

(4) Al-Bayt Al-Bhatri from his poem in praise of Al-Mu'taz. Parable: Similar and likeness. See: Diwan Al-Buhtari 3/1657, Clarification 2/157, and Wedding Bride $1 / 377$.

(5) Surah Yunus, some verse: 25.

(6) What is in parentheses is not in (p).

(7) Surat Al-A'raf, some verse: 143.

(8) Surat Al-Duha, verse: 1-3.

(9) That is, the private parts. And the hadeeth is from the words of Aisha, may God be pleased with her. Al-Hafiz IbnHajar mentioned this hadith in Al-Lisan (2/9), and he said: "Baraka was unique to him."

(10) What is in parentheses is not in (x).

(11) SuratGhafir, some verse: 28.

(12) That is, taking into account the commas in the verses, and their coming in a single format.
"(1), and in the manner of the subject over other than the original (2).

\section{Sources and References}

\section{Reference}

[1] Asrar al-Balaghah fi al-Bayan science, author: Abu BakrAbd alQaher al-Jarjani (deceased: $471 \mathrm{AH}$ )

[2] Origins in grammar, the author: $\mathrm{Abu}$ Bakr Muhammad, known as Ibn alSarraj (deceased: $316 \mathrm{AH}$ )

[3] The longest explanation of summarizing Miftah Al-Uloom, author: Ibrahim bin Muhammad bin ArabshahEssam al-Din al-Hanafi (T .: $943 \mathrm{AH}$ )

[4] Proverbs, the author: Abu Ubaid alQasim bin Salim bin Abdullah alHarawi al-Baghdadi (deceased: 224 $\mathrm{AH})$

[5] Al-Badi fi Al-Badi', the author: Abu al-Abbas, Abdullah bin Muhammad al-Mu'tazBillahIbn al-MutawakilIbn al-Mu'tasimIbn al-Rashid al-Abbasi (died: $296 \mathrm{AH}$ )

[6] Al-Bayan and Al-Tabiyyin, author: Amr bin Bahr bin Mahboub AlKinani, the famous Al-Jahiz (deceased: 255 A.H.)

[7] History of Islam, and the liabilities of celebrities and figures, author: Shams al-Din Abu Abdullah Muhammad bin Ahmad bin Othman al-Dhahabi

[8] The History of Damascus, the author: Abu al-Qasim Ali bin alHasan bin Heba Allah, known as IbnAsakir (deceased: $571 \mathrm{AH}$ )

[9] Editing inking in the making of poetry and prose and explaining the miracles of the Qur'an, author: Abdul-Azim bin Al-Wahid AlBaghdadi

[10] A group of proverbs, author: Abu Hilal al-Askari (deceased: c. 395 A.H.) 
[11] Al-Desouki's commentary on the summary of the meanings of Saad al-Din al-Taftazani (deceased: 792 A.H.)

[12] Visual enthusiasm, author: Ali bin Abi Al-Faraj bin Al-Hassan, Sadr Al-Din, Abu Al-Hassan AlBasri (deceased: 659 A.H.)

[13] Al-Hamasa Al-Buhtri, Author: Abu Ubada Al-Walid Bin Obaid Al-Buhtri (d.284 AH)

[14] The Literature Treasury and the Heart of the Bab Lisan Al-Arab, author: Abdul Qadir bin Omar AlBaghdadi (died: $1093 \mathrm{AH}$ )

[15] Characteristics, the author: Abu Al-Fath Othman bin Jani AlMawsili (deceased: 392 A.H.)

[16] Evidence for miracles in the science of meanings, author: $\mathrm{Abu}$ BakrAbd al-Qaher al-Jarjani (deceased: 471

[17] Diwan Al-Buhtri, explained by: Dr. Yusef Al-Sheikh Muhammad [18] Diwan Al-Ajaj, narrated by Abd al-Malik bin Qareb Al-Asma'i

[19] Divan Al-Mutanabi Publisher House Beirut, Lebanon

[20] The collection of the poetry of Al-Nabighah Al-Dhabiani, compiled and explained by Sheikh Muhammad Al-TaherIbnAshour

[21] The flower of morals and the fruit of hearts, author: Ibrahim bin Ali bin Tamim al-Qayrawani (died: $453 \mathrm{AH}$

[22] Zahr Al-Akam in Proverbs and Ruling, author: Al-Hassan bin Masoud bin Muhammad Al-Yusi (died: 1102 A.H.)

[23] The Secret of Eloquence, author: Abu Muhammad Abdullah bin Muhammad bin Saeed bin Sinan al-Khafaji (deceased: $466 \mathrm{AH}$ )

[24] Explanation of the Ten Poems, author: Yahya bin Ali al-
Tabrizi, Abu Zakaria (deceased: 502 $\mathrm{AH})$

[25] Explanation of the Seven Muallaqaat, author: Hussain bin Ahmad bin Husayn Al-Zawzni, (deceased: 486 A.H.)

[26] Explanation of the evidence of al-Mughni, Jalal al-Din al-Suyuti (died: 911 A.H.)

[27] Explaining the paradoxes of Jarir and Al-Farazdaq, author: Abu Ubaidah Muammar bin AlMuthanna.

[28] Wedding Bride Explaining Summers Al-Muftah, Bahaa Al-Din Al-Subki (died: 773 A.H.)

[29] Sciences of Rhetoric "AlBayan, Al-Maani, and Badi", author: Ahmed bin Mustafa Al-Maraghi (died: $1371 \mathrm{AH}$ )

[30] Al-Umda in the Beauties of Poetry and Its Literature, Author: Abu Ali al-Hasan ibnRasheeq alQayrawani (deceased: $463 \mathrm{AH}$ )

[31] Uyun al-Akhbar, author: Abu Muhammad Abdullah bin Muslim bin Qutaybah al-Dinuri (deceaslUzair Al-Qadi Al-Jarjani (deceased: $392 \mathrm{AH})$ 